\title{
PERAN KEARIFAN LOKAL KUMA DALAM MENDUKUNG EKONOMI KELUARGA PEREMPUAN DAYAK BANYADU
}

\author{
Benedhikta Kikky Vuspitasari, dan Angelus Ewid \\ STIM Shanti Bhuana Jalan Bukit Karmel No.1 Bengkayang 79211, Kalimantan Barat \\ E-mail : kikky@shantibhuana.ac.id, ewid@shantibhuana.ac.id
}

\begin{abstract}
ABSTRAK. Rendahnya penghasilan ekonomi keluarga menyebabkan perempuan di Dusun Simpang Tiga melakukan kegiatan Kuma dengan upah berupa beras dan uang, keterbatasan lahan yang dimilki serta rendahnya penghasilan suami merupakan faktor utama. Tujuan dari penelitian ini ingin menemukan dan merumuskan bagaimana meningkatkan peran kearifan lokal kuma dalam mendukung ekonomi keluarga bagi perempuan dayak Banyadu, kemudian faktor faktor apa saja yang mendukung dan menghambat peran kearifan lokal kuma dalam mendukung ekonomi keluarga bagi perempuan dayak Banyadu. Penelitian ini menggunakan pendekatan penelitian kualitatif fenomenologi dengan metode pengumpulan data, melalui observasi dan wawancara mendalam, pemilihan sampel menggunakan metode purposeful sampling sebanyak enam orang. dari hasil penelitian ditemukan bagaimana meningkatkan peran kearifan lokal kuma dalam mendukung ekonomi keluarga bagi perempuan dayak Banyadu yaitu melalui pelatihan berbasis pemberdayaan dimana kegiatan tersebut terdiri dari 7 tahap tahap diantaranya tahap menyadarkan masyarakat yang terdiri dari Koordinasi, analisis situasi dan menggali potensi diri dan potensi desa. Tahap peningkatan kemampuan masyarakat melalui persiapan pelatihan, pelatihan dasar. Tahap penerapan yang terdiri dari, menentukan jenis usaha berdasarkan potensi, memulai usaha serta tahap mendapatkan pelatihan berkesinambungan yang tujuannya untuk memberikan pelatihan berkelanjutan sesuai dengan permasalahan yang mereka alami dilapangan. Dalam melakukan kegiatan pelatihan tersebut diperlukan narasumber yang memiliki keahlian dibidangnya agar materi yang diberikan tepat sasaran dan bermanfaat bagi perempuan di dusun Simpang Tiga. Dukungan dari pemerintah terutama pemerintah desa khususnya desa Untang dusun Simpang Tiga baik pemerintah kabupaten, pemerintah desa dan masyarakat dusun Simpang Tiga, harapannya semakin banyak yang ikut berpartisipasi semakin banyak masyarakat menerima manfaatnya serta merasakan dampaknya dan menerapkannya dalam kehidupannya.
\end{abstract}

Kata kunci: Kearifan lokal; Ekonomi; Perempuan; Dayak; Banyadu

\section{THE ROLE LOCAL WISDOM OF KUMA IN SUPPORTING THE FAMILY ECONOMY FOR THE DAYAK WOMEN OF BANYADU}

\begin{abstract}
The low family economic income causes women in Simpang Tiga sub-village to do Kuma activities with wages in the form of rice and money, limited land ownership and low income from the husband are the main factors. The purpose of this study is to find and formulate how to increase the role of Kuma's local wisdom in supporting family economics for Banyadu Dayak women, then what factors support and hinder the role of Kuma local wisdom in supporting family economy for Dayak Banyadu women. This study uses a phenomenological qualitative research approach with data collection methods, through observation and in-depth interviews, sample selection using a purposeful sampling method of six people. From the results of the study it was found how to increase the role of Kuma's local wisdom in supporting family economics for Banyadu Dayak women through empowerment-based training in which the activity consisted of 7 stages including the community awareness stage consisting of coordination, situation analysis and exploring the potential and potential of the village. The stage of community capacity building through training preparation, basic training. The implementation phase consists of, determining the type of business based on potential, starting a business and the stage of obtaining ongoing training whose aim is to provide ongoing training in accordance with the problems they experience in the field. In carrying out the training activities, resource persons with expertise in their fields are needed so that the material provided is right on target and useful for women in the Simpang Tiga hamlet. Support from the government, especially the village government, especially the Untang village, Simpang Tiga sub-village, both the district government, village government and the community of Simpang Tiga sub-village, hopes that more people will participate and the more the community will receive the benefits and feel the impact and apply them in their lives.
\end{abstract}

Key words: Local Wisdom; Economy; Women; Dayak, Banyadu

\section{PENDAHULUAN}

Sejak dahulu nenek moyang kita telah mengajarkan banyak kearifan lokal, semua itu melakat dalam susunan kehidupan bermasyarakat kita diantaranya dalam hidup bersosial, berbudaya hingga dalam lingkungan bermasyarakat, melalui kearifan lokal yang teruang dalam nilainilai tradisional yang terus digunakan dan diterapkan oleh kebanyakan masyarakat lokal. Isi dari kearifan lokal tersebut membahas mengenai sekumpulan aturan dan ilmu pengetahuan yang berkaitan dengan nilai-nilai etika yang memberikan pandangan dalam bertingkah laku dan bagimana hidup bersosial dalam masyarakat semua itu selaras dengan perkembangan zaman.

Kearifan lokal ada karena adanya konflik yang terjadi didalam masyarakat yang menjadi sarana dalam memecahkan konflik tersebut, dimana dalam penyelesaian konflik disesuaikan dengan konflik yenag terjadi dilingkungan masyarakat. konflik ini sering kali terjadi dalam berbagai aspek kehidupan, aspek sosial terkadang sering kali menjadi permasalahan yang umumnya terjadi di kehidupan saat ini bahkan sering kali menjadi konflik yang 
sulit diselesaikan jika masyarakat terlalu mementingkan kepentingannya sendiri oleh karena itu kearifan lokal muncul sebagai solusi dalam memecahkan konflik tersebut dan menjadi pengetahuan baru bagi masyarakat hingga menjadi milik bersama.

Masyarakat lokal sangat mengenal kearifan lokal dengan baik karena disanalah kearifan lokal berkembang dan muncul pertama kali, munculnya kebiasaan dimulai saat mereka harus bekerja diluar rumah dan memerlukan bantuan orang lain untuk menyelesaikan pekerjaan tersebut. Membuka lahan untuk berladang dan menanam padi disawah salah satu contohnya, ini merupakan salah satu contoh bagaimana kebiasaan tersebut muncu dan menjadi tradisi sehingga muncullah kearifan lokal. Kearifan lokal ada kerana adanya kebiasaan yang menghasilkan suatu tindakan yang menciptakan suatu sikap dalam menghadapi peristiwa tersebut kemudian menyebabkan terjadinya suatu ekspresi yang bermacammacam salah satunya adalah tradisi adat istiadat, karya seni sampai cara berfikir manusia sehingga membentuk suatu kearifan lokal (Azizah, 2017:68), karena masyarakat sudah lama mengenal kearifan lokal tersebut sehingga mereka secara turun temurun menggunakan kebiasaankebiasaan untuk menghasilkan sesuatu dalam memenuhi kehidupannya namun semua itu tergantung dari masyarakat lokal itu sendiri karena semua tergantung dari bagai mana mereka bersikap dan bertingkah laku. Namun di zaman modern saat ini kearifan lokal dapat dipercaya memberikan dampak yang baik bagi kesatuan hidup bermasyarakat, dengan bersatunya semua unsur yang ada dimasyarakat akan sangat mudah masyarakat dalam menyuarakan inspirasi, ide bahkan gagasan yang dapat membantu masyarakat dalam menyelesaikan permasalahan didalam kehidupannya salah satunya adalah bagaimana permasalaha ekonomi mereka dapat diatasi, menjalin kehidupan bertetangga yang baik hingga menjaga kekompakan dalam bekerja, semua itu tercipta karena adanya adanya ikatan saling membutuhkan di lingkungan masyarakat semua ini tertuang dalam (Sopa, 2018:525)

Kearifan lokal menjadi sebuah tanda bagaimana masyarakat dalam menjalani kehidupannya dan mendapatkan pengalaman hidup dan semua itu diterapkan dalam keseharian mereka dan menjadi satu pandangan hidup bermasyarakat dalam bertindak dan mengambil keputusan. (Pattinama, 2009:1) menegaskan bahwa munculnya kearifan lokal dapat membantu masyarakat lokal mengatasi permasalahanya melalaui potensi yang ada di masyarakat dan dapat dikembangkan, melalui potensi tersebut harapannya masyarakat dapat berkembang, ekonomi meningkat, masyarakat sejahtera dan kemiskinan yang ada dimasyarakat dapat diturunkan jumlahnya, semua itu dapat terjadi karena didalam kehidupan masyarakat lokal nilai kehidupan tradisional dapat membentuk kehidupan yang setara antara manusia dan alam, namun semua itu terjadi tidak terlepas dari gaya hidup dan kebutuhan masyarakat itu sendiri.

Kearifan lokal akan lebih terasa didalam kehidupan masyarakat ketika mereka mengalami musibah (Utama, 2013:1) Seperti yang terjadi di Aceh kearifan lokal sangat terasa ketika bencana alam tsunami pada tahun 2004, yaitu kearifan lokal Smong untuk mengurangi resiko bencana. Selain itu (Sungkharat, 2010:302) menyatakan kegiatan penerapan peningkatan kearifan lokal dapat dilakukan melalui pelatihan yang disampaikan kepada masyarakat, semua itu diseuaikan dengan lingkungan masyarakat setempat dengan memperhatikan nilai-nilai budaya yang ada di masyarkat sehingga mereka akan mudah menerima dan menerapkannya. (Kamonthip, 2007:2) bahwa dalam mengembangkan kehidupan masyarakat melalui kearifa lokal Sangat penting karena didalamkehidupan masyarakat biasanya mereka akan membentuk suatu kelompok besar maupun kelompok kecil yang akan membentuk suatu komunitas sehingga melalui kelompok tersebut mereka akan banyak berbagi pengetahuan dan pengalaman sehingga tercipta kehidupan yang berkenajutan dengan cara seperti itu akan memberikan pengaruh yang baik bagi kelangsungan hidup mereka, semua itu sangat bermanfaat dimana masyarakat yang terlibat adalah masyarakat yang ingin meningkatkan ekonominya.

Namun untuk mewujudkan itu semua pemerintah desa semestinya ikut mendukung dan berpartisipasi. Nilainilai luhuryang terkandung dalam kearifan lokalmempunyai pengaruh yang besar untuk menangkal permasalahan sosial dan budaya yang ada di masyarakat ditengah munculnya teknologi yang masuk dalam kehidupan masyarakat, hingga cukup membuat kita prihatin karena semakin banyak masyarakat mulai melupakan arti penting dari nilainilai yang dihasilkan oleh kearifan lokal. Nilai-nilai yang ada dalam kearifan lokal membawa kita mengetahui dan mengajarkan kita bagimana berperilaku, bersikap dan saling menghargai (Neni Rahmawati, 2012:17)

Melihat perkembangan zaman yang semakin maju serta dampak yang ditimbulkan. Perlu media atau sarana yang diberikan melalui penerapan nilai-nilai kearifan lokal yang ditanamankan di sekolah dan di rumah melalui pendidikan formal maupun informal sehingga kearifan lokal ini dapat terus dilestarikan dan hingga generasi muda mengetahui bahwa kearifan lokal adalah warisan dari leluhur kita yang harusnya diterapkan dalam kehidupan bermasyarakat sesuai dengan kebutuhannya. Kearifan lokal tersebar diseluruh wilayah yang ada di Indonesia salah satunya yang ada di Kalimantan Barat, terletak di kabupaten Landak.

Kearifan lokal Kuma merupakan salah satu kebiasaan atau tradisi yang dimiliki oleh dayak Banyadu dalam berladang dan bersawah. Tradisi ini sering kali dijalankan 
oleh masyarakat lokal yang berdiam di Dusun Simpang Tiga, tradisi Kuma bagi masyarakat Dusun Simpang tiga dilakuka terus menerus oleh masyarakat yang memiliki sawah dan ladang, kegiatan ini biasanya melibatkan kaum perempuan dalam membantu menyelesaikan pekerjaan mereka.

Kata Kuma merupakan berasal dari bahsa yang sering kali mereka gunakan yaitu Nguma (Silvi, Agustine Lumangkun, 2017:1032). Tradisi kuma yang sudah mereka terapkan merupakan kearifan lokal yang sudah ada dari dahulu dan hingga saat ini masih dilakukan Oleh para wanita dayak Banyadu dalam memenuhi kebutuhan keluarganya. Dalam kesehariannya para wanita yang terbiasa dengan pekerjaan disawah dan diladang akan memanfaatkan Kuma sebagai penunjang dalam membantu memenuhi kebutuhan hidup sehari-hari, dari pekerjaan Kuma mereka akan mendapatkan upah. semua disebabkan tidak ada sumber penghasilan lain di dusun tersebut, kebutuhan yang sangat banyak sehingga mereka juga terlibat dalam memenuhi kebutuhan tersebut, (Elizabeth, 2008:63) menyatakan bahwa para wanita petani yang kesehariannya melakukan pekerjaan pertanian akan terlibat aktif mencari sumber penghasilan lain, semakin banyak pekerjaan yang akan mereka lakukan semakin banyak pula tenaga dan energi yang mereka curahkan untuk pekerjaan tersebut. Semakin rendah tingkat ekonomi keluarga wanita petani tersebut maka akan semakin banyak aktivitas pekerjaan yang mereka lakukan untuk menghasilkan uang guna menunjang ekonomi keluarga (Frida Nur Rizkia, 2017:408) menyatakan bahwa wanita yang mempunyai keinginan membantu suami dalam meningkatkan perekonomian keluarga sering kali melakukan pekerjaan berkebun, berdagang sampai menjadi buruh pabrik semua itu dilakukan demi keberlangsungan hidup keluarga. (Khusnul Khotimah, 2009:166) menyatakan hampir mayoritas yang bekerja sebagai buruh tani adalah wanita dan faktor penyebabnya adalah pendidikan dan kemiskinan.

Untuk itu dapat disimpulkan wanita petani mempunyai peran yang sangat penting dalam kehidupan keluarga. Selain wanita petani mencari penghasilan dalam membantu suami, mereka juga harus mengurus rumah tangga mulai dari masak dan mengurus anak, peran ganda yang mereka janlani menunjukan bahwa wanita petani adalah wanita yang hebat namun perlu adanya perhatian dari pemerintah maupun pemerintah desa yang diberikan untuk kelangsungan hidup wanita petani sehingga mereka tidak bergantung pada kegiatan Kuma sebagai sumber penghasilan keluarga, hal ini didukung dari hasil penelitia (S. Boakye-Achampong dkk. 2012:3839) menyatakan bahwa kemampuan wanita petani dalam mengolah hasil pertanian masih tergolong sangat rendah untuk itu pemerintah semestinya mendukung melalui kegiatan diluar pertanian yaitu pemberdayaan masyarakat dalam bentuk pelatihan, tujuannya adalah meningkatkan penghasilan mereka terutama rumah tangga sehingga sumber penghasil mereka tidak hanya satu namun dapat menemukan sumber penghasilan lain.

Hasil penelitian dari (Bambang dkk, 2013) model community development merupakan salah satu model yang cocok diterapkan dalam lingkungan masyarakat yang mayoritas wanita petani, implementasinya adalah pelatihan-pelatihan yang dilakukan untuk meningkatkan kemampuan mereka, pelatihan yang diberikan bersifat informal seperti yang disampaikan oleh Surakman dalam (Suharto, 2016: 335-336) bahwa konsep pendidikan yang dijalankan dilingkungan masyarakat adalah 1. Mereka yang mempunyai kesadaran yang tinggi tentang pentingnya pendidikan; 2. Mereka yang peka akan pendidikan; 3. Sadar akan manfaat pendidikan, karena melalui pendidikan mereka mampu bersaing; 4. Sadar bahwa mereka yang mendukung pembiayaan da pengadaan sarana pendidikan. Artinya pendidikan yang dijalani oleh masyarakat adalah hasil dari kesadaran mereka diantaranyapenyediaan sarana pendidikan serta pembiayaan, melalui pendidikan yang mereka jalani semua itu dapat memajukan kehidupan mereka dan menghapus mereka dari ketertinggalan.

Saat mereka tau bahwa pendidikan sangat penting maka mudah menerapkan pelatihan-pelatihan yang diberikan dan sadar bahwa pelatihan tersebut sangat bermanfaat bagi kehidpan sosial, budaya dan ekonomi. Pelatihanpelatihan yang diberikan hendaknya memasyarakatkan mereka untuk lebih aktif diantaranya pelatihan berbasis masyarakat dimana dalam kegiatan ini para perempuan diajak berkumpul bersama untuk menggali kemampuan mereka, seperti yang diketahui bahwa pemberdayaan menurut (Diah, 2019:154-155) adalah salah satu cara untuk meingkatkan kemampuan masyarakat yang kurang mampu termasuk masyarakat yang mengalami kemiskinan, ada tiga tahap proses pemberdayaan yang dilakuka yaitu tahap penyadaran, pengkapasitasan dan pendayaan.

Tahap yang pertama yaitu tahap penyadaran dimana tahap ini masyarakat diberi ilmu atau pengetahuan tentang suatu hal yang membuka pikiran mereka sehingga mereka menjadi tau atau bahkan masyarakat yang tidak peduli menjadi tertarik sehingga melalui pengetahuan yang mereka dapatkan semakin menguatkan mereka untuk lebih terpacu melakukan kegiatan usaha atau kegiatan yang dapat bermanfaat bagi orang banyak. Tahap kedua yaitu pengkapasitasan, pada tahap ini masyarakat diminta untuk dapat meningkatkan kemampuan mereka melalui kegiatan pelatihan yang diberikan tujuannya dengan pelatihan, mereka mendapatkan pengetahuan dan segera menerapkannya, contohnya para perempuan dapat mengetahui cara mengolah, para perempuan dapat 
mengetahui cara mengemas suatu produk, para perempuan mengetahui cara memasarkan, para perempuan mengetahui bagaimana cara manajemen usaha serta para perempuan mengetahui bagimana cara mengelola keuangan usaha yang dimilikinya, melalui kegiatan pelatihan yang dilakukan hal-hal seperti ini tentunya tidak semua mereka peroleh di bangku sekolah dasar dan tentunya setelah mengetahui kegiatan pelatihan mereka menjadi tahu.

Tahap selanjutnya tahap pendayaan, yang dilakukan oleh para perempuan selanjutnya adalah mereka membuka usaha secara mandiri dan menerapkannya dengan baik dilingkungan tempat tinggal mereka, melalui penerapan yang baik tentunya akan menjadi contoh bagi perempuanperempuan yang lainnya untuk lebih dapat giat lagi untuk mengelola usaha dengan baik sehingga usaha tersebut dapat berjalan dan bersaing sesuai dengan perkembangan zaman.

Kearifan lokal dimiliki oleh setiap daerah tentunya memiliki keunikan tersendiri dan dapat dijadikan sarana dalam meningkatkan ekonomi masyarakat, Penghasilan ekonomi keluarga menyebabkan perempuan di Dusun Simpang Tiga melakukan kegiatan Kuma dengan upah sebesar Rp. 50.000 dan beras, keterbatasan lahan yang dimilki serta rendahnya penghasilan suami merupakan faktor utama. Tujuan dari penelitian ini ingin menemukan dan merumuskan bagaimana meningkatkan peran kearifan lokal kuma dalam mendukung ekonomi keluarga bagi perempuan dayak Banyadu, kemudian faktor-faktor apa saja yang mendukung dan menghambat peran kearifan lokal kuma dalam mendukung ekonomi keluarga bagi perempuan dayak Banyadu. penelitian ini ingin memberikan gambaran bagaimana konsep kearifan lokal dapat digunakan dan diterapkan untuk meningkatan ekonomi masyarakat khusunya di dusun Simpang Tiga. Dengan konsep hasil penelitian tersebut harapannya desa dapat menerapkan konsep tersebut.

\section{METODE}

Penelitian ini adalah penelitian kualitatif fenomenologi, menurut (Slamento, 2015:71) penelitian kualitatif adalah "sebuah penelitian yang menghasilkan data deskriptif berupa kata-kata tertulis maupun lisan dari narasumber yang dicermati dengan hasil yang diperoleh berupa tindakan atau kata-kata, sering digunakan untuk menghasilkan teori yang timbul bukan dari hipotesishipotesis seperti dalam penelitian kuantitatif'. Penelitian fenomenologi adalah penelitian yang mempelajari bagaimana suatu kejadian yang dialami dalam kesadaran, pikiran dan dalam tindakan seperti bagaimana fenomenologi tersebut bernilai atau dapat diterima secara estetis, kesimpulannya bahwa penelitian kualitatif fenomenologi adalah penelitian yang hasilnya dapat dijadikan teori berdasarkan pengalaman-pengalaman yang dialami oleh narasumber.

Fokus penelitia ini adalah kegiatan Kuma yang dilakukan oleh para wanita tani dayak Banyadu dalam memenuhi kebutuhan ekonomi keluarga, sumber data dari kegiatan penelitian ini adalah para wanita tani yang berasal dari dusun Simpang Tiga Kabupaten Landak Tehnik pengumpulan data yag digunakan adalah menggunakan purposeful sampling dengan narasumber sebanyak 6 orang dengan cara wawancara mendalam bertujuan untuk mendapatkan informasi serta menjawab masalah yang ada pada penelitian ini.

Teknik Analisis Data Analisis penelitian fenemenologi menurut Creswell dan Moustakas dalam (Siti Kholifah, 2018:17) adapun hal-hal yang perlu diperhatikan dalammenganalisispenelitianfenomenologiadalahsebagai berikut :1. Mendeskripsikan secara lengkap peristiwa yang telah dialami narasumber melalui penulisan transkrip hasil wawancara; 2. Tahap horizontal, melalui hasil wawancara berupa transkrip peneliti menginventarisasi pernyataanpernyataan penting yang sesuai dengan topik; 3. Tahap clauser of meaning : (pengelompokan makna) selanjutnya peneliti membuat klasifikasi dari pernyataan-pernyataan yang penting ke dalam tema-tema atau unit-unit makna, serta dapat menyisihkan pendapat yang tumpang tindih dimana dalam tahap ini deskripsi struktural dimana semua hal yang terjadi pada informan ditulis sesuai denga konteks fenomena itu terjadi; 4. Tahap deskripsi esensi : dimana peneliti membangun deskripsi secara menyeluruh menegani makna dan esensi pengelaman informan. Peneliti melaporkan hasil penelitian, dimana hasil laporan memberika pemahaman kepada pembaca sehingga pembaca dapat mengerti akan hasil penelitian tersebut.

\section{HASIL DAN PEMBAHASAN}

\section{Kearifan lokal kuma membantu ekonomi keluarga}

Tradisi kuma yang sudah diterapkan turun temurun oleh Dayak Banyadu merupakan kearifan lokal yang sudah ada dari dahulu dan hingga saat ini masih dilakukan oleh para wanita prtani dayak Banyadu dalam memenuhi kebutuhan keluarganya. Dalam kesehariannya para wanita yang terbiasa dengan pekerjaan disawah dan diladang akan memanfaatkan kuma sebagai penunjang dalam membantu memenuhi kebutuhan hidup sehari-hari, dari pekerjaan Kuma mereka akan mendapatkan upah. semua disebabkan tidak ada sumber penghasilan lain di dusun tersebut, kebutuhan yang sangat banyak sehingga mereka juga terlibat dalam memenuhi kebutuhan keluarga. kegiatan kuma dilakukan oleh para wanita tani biasanya berhugbungan dengan kegata pertanian yaitu merumput, menanam, menebas, memanen padi yang ada di ladang. 
Kegiatan kuma digunakan untuk memenuhi kebutuhan dapur mereka seperti yang diutarakan oleh narasumber LN menggunakan bahasa setempat

.... kai kuma biasa kan magaji Rp. 50.000,- sakali kuma dakoh biasa yak mari binyak, sia gik dongkayu...

(Yang artinya kami digaji sebesar Rp.50.000/ hari, uang digunakan untuk membeli keperluan sehari-hari seperti minyak goreng, garam dan sayur).

Ditengah kesulitan ekonomi yang mereka rasakan kegiatan Kuma menjadi solusi untuk memecahkan permasalahan ekonomi keluarga, manfaat lain yang dirasakan oleh narasumber LIN adalah mereka bisa menggunakan hasil kegiatan Kuma untuk membayar listrik dan bekal jajan untuk anak-anak mereka yang masih duduk di bangku sekolah.

.....uang dari kuma dakoh yakjajan anak gik mayar listrik... (uang dari hasil Kuma untuk jajan anak dan bayaran listrik)

Penghasilan keluarga yang tidak cukup untuk memenuhi kebutuhan sehari-hari, dimana penghasilan suami juga tidak menentu dan tidak ada sumber penghasilan lain bagi para wanita sehingga mereka harus ikut bekerja, seperti yang dikemukan oleh (Frida Nur Rizkia, 2017:408) bahwa wanita yang bekerja sebagai petani, berdagang atau buruh pabrik mempunyai tujuan yaitu membantu suami dalam memenuhi kebutuhan sehar-hari, kurangnya penghasilan suami sehingga istri juga harus kreatif mencari penghasilan tambahan guna kelangsungan memenuhi kebutuhan rumah tangga seperti yang disampaikan narasumber $\mathrm{SJ}$

.... banun ko ndu tantu penghasilan ne, kalau kuma adu uga yak keperluan da ka raminlah kadang kan minis utuk nabung uga ....

(.....penghasilan suami saya tidak menentu, dari hasil kuma di pakai untuk keperluan di rumah terkadang disimpan untuk ditabung..... )

Pekerjaan di ladang dan disawah merupakan pekerjaan sudah biasa dilakukan oleh mereka, karena mereka sudah terlibat sejak kecil oleh orang tua, diajarkan cara menanam, merumput, memanen semua kegiatan tersebut benar-benar dijalankan secara tradisional, tingkat pendidikan dan rendahnya kreativitas yang mereka miliki menjadikan mereka terbiasa dengan keadaan saat ini, seperti yang disampikan oleh (Khusnul Khotimah, 2009:163) menyatakan hampir mayoritas yang bekerja sebagai buruh tani adalah wanita dan faktor penyebabnya adalah pendidikan dan kemiskinan.

.....Ikin hanya sakolah sampe kalas 4 SD ta, nak ngalanjut sakolah meh ndu ba uang. Dakoyu ngate sakolah meh dama ndu mampu mayar uang sakolah, daripada moko ka ramin baik mungkut. Pamungkut da pertama kin kaatn ka Pontianak jad babysitter so mungkut pamungkut da ka dapur uga. Kadang gaji e meh kan ngirim ka dama uga....

(......saya hanya sekolah sampai di kelas 4 SD, untuk melanjutkan sekolah orang tua tidak punya biaya sehingga saya memilih untuk bekerja, tujuan pertama saya bekerja di Pontianak dan pekerjaan saya sebagai babysitter merangkap asisiten rumah tangga, gaji yang saya peroleh saya gunakan untuk keperluan pribadi dan dikirim untuk orang tua....).

Keadaan ekonomi orang tua membuat mereka tidak melanjutkan pendidikan. Walaupun keinginan mereka untuk melanjutkan sekolah ada, pilihan yang mereka lakukan bekerja dengan kemampuan dan pengalaman yang minim diusia yang masih dini membuat mereka harus bekerja memenuhi kebutuhan hidup keluarga. memanfaakan pengetahuan yang diberikan orang tua yang sudah mengajarkan mereka untuk bekerja di sawah, mereka sudah terbiasa merumput, menebas, memanen karena itu hingga dewasa mereka sudah terbiasa melakukannya. Tidak punya pilihan karena keterbatasan pendidikan yang dimiliki, hanya pengalaman yang mereka punya dari orang tua sebagai modal untuk tetap bekerja memenuhi kebutuhan hidup. Lahan pekerjaan yang minim perusahaan-perusahaan tidak ada hanya lahan yang bisa digarap untuk sawah jika tidak ada lahan mereka memilih bekerja di sawah milik tetangga bekerja mengharapkan upah seperti yang terjadi dengan narasumber LN :

......ndu ba pamungkut lain ka diah meh, nak nguma ndu ba tana. Perusahaan-perusahaan pun nyandu ka daerah adup diah nyandu ba pamungkut lain meh kuma ta.....

(........tidak ada pekerjaan lain di sisni, mau berladang tidak ada lahan. Perusahan-perusahaan juga tidak ada di tempat kita, tidak ada pekerjaan lain kecuali Kuma...)

Sumber penghasilan yang minim, serta lapangan pekerjaan yang minim, menyebabkan mereka mengandalkan Kuma. Di dusun Simpang Tiga mempunyai banyak potensi alam yang belum dimaksimalkan oleh masyarakat setempat, keterbatasan pengetahuan serta pengalaman dalam mengolah sesuatu yang tidak mereka miliki seperti yang di sampaikan narasumber LIN:

........ka adup diah bangat potensi adu jagong, angale, pade tapi bah ndu pane ngolah e......

(........potensi di Simpang Tiga banyak seperti jagung, ubi dan padi tapi tidak tau mengolahnya....)

Secara geografis dusun Simpang Tiga memiliki wilayah pegunungan yang terdiri dari hutan dan lembah, 
dari hutan yang mereka miliki menghasilkan tumbuhtumbuhan yang banyak manfaatnya, tidak semua tanamana dimanfaatkan oleh masyarakat sekitarnya, contohnya mereka memanfaatkan tanamana yang terdapat dihutan tersebut untuk mencari tanaman yang dapat dimanfaatkan sebagai sayuran yang dapat dikonsusmsi oleh keluarga dan dimanfaatkan dijual kembali, tanaman-tanaman tersebut adalah tanaman lokal yang biasa mereka manfaatkan untuk dimasak. Di hutan terdapat bambu dan rotan namun rotan saat ini sudah mulai jarang ditemui di hutan sekitar mereka, potensi lainnya di sekitar dusun Simpang Tiga mayoritas memanfaatkan lahan untuk persawahan namun untuk hasil belum maksimal. Masih banyak lahan tidur yang belum dimanfaatkan secara maksimal. Perhatiaan oleh pemerintah dibidang pertanian juga masih belum maksimal dijalankan belum ada kelompok-kelompok petani yang berhasil dalam mengelola hasil pertanian, karena melalui kelompok-kelompok tani tersebut mereka bisa membentuk gabungan kelompok tani atau biasa di sebut dengan Gapoktan seperti yang disampaikan oleh Narasumber LIN

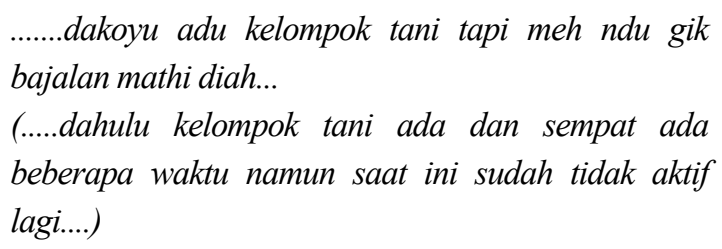

Kurangnya pengetahuan dalam mengelola potensi alam yang dimiliki menjadi salah satu kendala bagi masyarakat disekitar untuk dapat beralih ke sumber penghasilan lain kecuali mengolah sawah, masyarakat belum banyak memanfaatkan lahan-lahan yang kosong tersebut untuk hal lain seperti berkebun sayur, dengan berkebun sayur mereka tidak akan mengambil sayuran di hutan, karena sayuran di hutan tidak akan selamanya ada, suatu saat pasti akan punah jika masyarakat tidak beralih menanam sayuran sendiri, masyarakat juga terbiasa dengan sayuran yang dibawa oleh para penjual sayur yang berasal dari daerah setempat namun mereka berbelanja ke Singkawang untuk mendapat stok sayuran yang mereka jual ke masyarakat sekitar, hal ini sebenarnya peluang bagi masyarakat di Simpang Tiga untuk membuat kebun sayuran tentunya dapat menghasilkan sumber ekonomi baru bagi keluarga, namun inisiatif ini belum ada hingga saat ini. Semua itu berkaitan dengan pengetahuan mereka dalam melihat peluang serta keterbatasan pengetahuan dan keterampilan. Untuk itu diperlukan sarana yang dapat bermanfaat bagi mereka untuk mendapatkan ilmu baru yang dapat mereka manfaatkan untuk mengembangkan diri, membuka wawasan mereka untuk dapat melihat peluang yang ada di sekitar mereka melalui pelatihan seperti yang di ungkapkan oleh narasumber SJ: .....ikin itu bah ikut pelatihan kalau adu wah umas kerajinan tangan ...

( ....saya mau saja ikut pelatihan seperti pelatihan kerajianan tangan.....)

Kerinduan mereka untuk mendapatkan pengetahuan baru melalui pelatihan sangat diharapkan oleh para narasumber yang kami temui, keinginan ini juga di sampaikan oleh narasumber lainnya seperti yang disampikan narasumber MJ

.....Ndu pernah kin ikut pelatihan kalau adu meh itulah supaya kaatn pengalaman ....

(......Saya tidak pernah ikut pelatihan kalau ada saya akan megikutinya agar dapat pengalaman baru...)

Keinginan untuk mendapat pengetahuan baru, sepertinya sudah ada dalam benak mereka, hanya mereka tidak tau bagaimana cara mengungkapkannya kepada pihak yang dituju khususnya bagi pemerintah setempat, keinginan untuk mengubah pemikiran mereka sehingga mereka punya pemikiran baru dan bisa dikembangkan seperti yang dikemukakan oleh narasumber LIN:

.....Kalau adu pelatihan untuk kai kin bersyukur sekali supaya adu pengetahuan baru da kan kai kaatn kiah bangat potensi tapi ndu pane ngolah e.....

(.......Kalau ada pelatihan saya bersyukur sekali supaya kami dapat pengetahuan baru karena disini banyak potensi tapi tidak tau mengolahnya .... )

Saat itu keinginan pelatihan ini sempat di utarakan dan ditanyakan apakah selama ini pemerintah desa pernah atau tidak melakukan kegiatan pelatihan guna memberikan ilmu baru ke pada masyarakat sebagai pesertanya. Seperti yang disampaikan salah satu staf desa

......dakoyu tahun 2016 pernah adu pelatihan, cara mencangkok batakng gatah tapi meh peserta ninik trus susah manso narasumber....

(...Pada tahun 2016 silam pernah diadakan pelatihan yaitu cara mencangkok pohon karet namun yang menjadi peserta sangat sedikit selain itu kesulitan dalam mencari narasumber menjadi kendala bagi kami....)

Hal serupa diutarakan oleh kepala desa bahwa dahulu pernah ada dilakukan pelatihan, jika memang ada kegiatan pelatihan desa akan mendukung namun untuk kegiatan tersebut tidak bisa dianggarkan dalam waktu dekat karena pada tahun ini pemerintah desa melalui anggaran dana Desa juga terfokus pada bidang pembangunan hal ini disampaikan oleh Kepala Desa :

....Pada tahun ini anggaran untuk peningkatan kapasitas hanya untuk kader kesehata saja mungkin tahun 2020 bisa dianggarkan untuk kegiatan tersebut... 
Dari hasil wawancara dan observasi yang dilakukan selama penelitian diatas ditemukan apa yang menjadi latar belakang perempuan dayak Banyadu menjalankan kegiatan Kuma diantaranya:

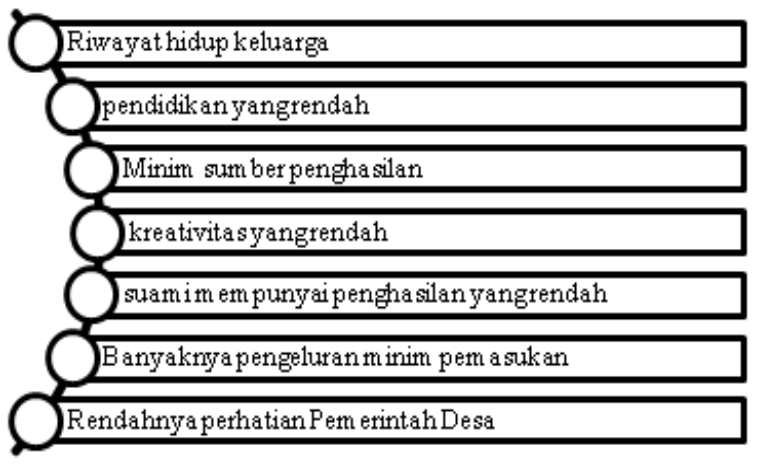

Gambar. 1 Latar belakang perempuan dayak Banyadu melakuka Kuma.

Berdasarkan latar belakang tersebut dapat disimpulkan kegiatan kuma dapat membantu memenuhi kebutuhan mereka sehari-hari semua itu didukung dari beberapa faktor salah satu rendahnya pendidikan yang mereka miliki. Manfaat kuma dapat dilihat dari dua sisi yaitu dari sisi ekonomi dan sisi sosial. Dari sisi ekonomi dapat memabantu para wanita dayak Banyadu mendapatkan penghasilan tambahan, dapat membantu suami, dapat memenuhi kebutuhan sehari-hari, dapat menabung, dapat memenuhi kebutuhan anak diantaranya uang saku atau uang jajan, menabung.

Dari segi sosial kegiatan kearifan lokal kuma mempunyai manfaat diantaranya menjaga hubungan baik dengan tetangga, mengurangi jumlah pengangguran antar perempuan, meningkatkan kerjasama, menghidupkan semangat gotong royong yang pada umumnya sudah hampir hilang dan tentunya akan punah jika tidak dilestarikan. Adapun manfaat kegiatan kuma dapat di gambarkan sebagai berikut:

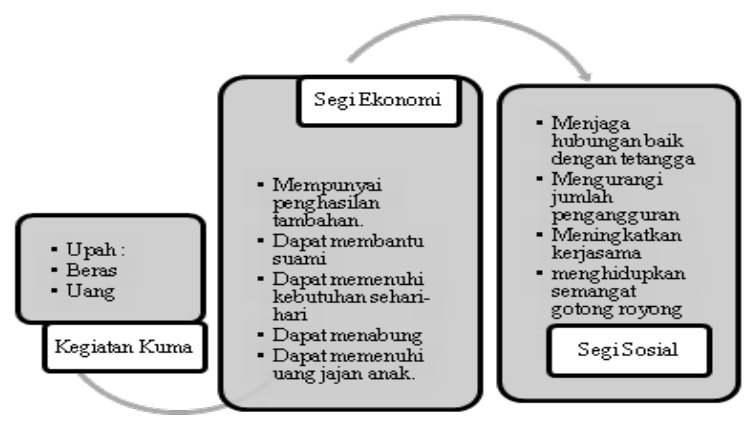

Gambar 2. Manfaat kegiatan kearifan lokal Kuma melakukan Kuma.

\section{Cara meningkatkan peran kearifan lokal Kuma}

Cara meningkatkan kegiatan kuma diperlukan suatu konsep kegiatan peningkatan kapasitas bagi para perempuan di dusun Simpang Tiga melalui pelatihan, pelatihan sebagai sarana belajar untuk mendapatkan pendidikan bagi masyarakat.
Kegiatan ini tentunya bermanfaat untuk meningkatkan peran kearifan lokal Kuma melalui pelatihan berbasis pemberdayaan, melalui pemberdayaan sumber daya manusia akan terbentuk sehingga terbentuk pulalah manajemen sumber daya manusia semua itu melalui pendidikan yang melibatkan guru dan murid sebagai sumber daya manusia (Kantirina Rachaju, 2019:20)

Untuk meningkatkan kemampuan sumber daya manusia, pelatihan yang diberikan merupakan bagian pendidikan yang dilakukan bersifat informal berupa pelatihan yang melibatkan masyarakat dan dapat memberikan dukungan kepada mereka untuk mendapatkan pengetahuan (Bambang Suswanto, 2013:311). Tentunya pendapat tersebut sejalan dengan apa yang ingin penulis sampikan bahwa pendidikan informal berupa pelatihan merupakan sarana yang wajib didapatkan oleh masyarakat yang lemah. Kegiatan pelatihan yang cocok dan sesuai agar peltihan tersebut tepat sasaran. (Suharto 2016;333-334) menyatakan pelatihan berbasis pemberdayaan merupakan sarana yang sangat tepat mengingat keadaan masyarakat yang tinggal di daerah Dusun tersebut, latar belakang masyarakat serta tradisi yang mereka jalani selama ini, seperti yang disampikan wrihatnolo dan Nugroho dalam (Diah, 2019:154-155) bahwa dalam melakukan kegiatan pelatihan berbasis pemberdayaan ada 3 tahap yang perlu diketahui dimana proses itu terdiri dari penyadaran, pengkapasitasan dan pendayaan. Dalam penelitian ini tahap penyadaran masyarakat diberi pengetahuan tentang kemampuan yang dimiliki serta potensi-potensi yang ada dilingkungan mereka dapat dimanfaatkan menjadi sesuatu yang sangat berguna dan memiliki nilai ekonomi. Penerapannya yang harus dilakukan ditahap penyadaran adalah sebagai berikut ditahap pertama dan kedua dimana tahap-tahap tersebut dapat dijelaskan sebagi berikut:

1. Tahap menyadarkan masyarakat. Dimana tahap awal yang harus dilakukan adalah tahap koordinasi mengumpulkan masyarakat terutama kaum perempuan yang ada di dusun tersebut tidak lupa mengajak serta kepala Desa beserta perangkat desa, diajak duduk bersama untuk membahas rencana kegiatan pelatihan,

2. Peningkatan kemampuan masyarakat. Pada tahap ini terdiri dari analisis situasi dan menemukan solusi serta menggali potensi-potensi yang ada di desa kemudian bekerjasama mengembangkan potensi yang akan dijadikan usaha. Selanjutnya rencana kegiatan pelatihan yang sesuai dengan potensi yang akan dikembangkan untuk menunjang kegiatan usaha para perempuan di Dusun tersebut dan menjalankan pelatihan dasar.

Dalam tahap ini para perempuan-perempuan tersebut di beri pengetahuan melalui minat dan kemampuan mereka, diantaranya kemampuan memenajemen suatu usaha, kemampuan dalam mengelola keuangan, kemampuan dalam memimpin serta kemampuan dalam memasarkan 
produk yang mereka hasilkan selanjutnya kemampuan dalam menginovasi suatu prodak sehingga prodak tersebut dapat bertahan dan mampu bersaing.

Persiapan pelatihan persiapan pelatihan perlu dilakukan diawal guna mempertimbangkan pelaksanaan kegiatan yang akan dilakukan menyangkut dimana akan dilakukan, lamanya kegiatan, biaya yang digunakan dan jenis pelatihan, waktu serta keterlibatan narasumbernarasumber yang berkopensi dibidangnya sehingga pelatihan tersebut tepat sasaran.

Kegiatan pelatihan ini diawali dengan pelatihan dasar, pelatihan ini bertujuan untuk mengenalkan potensi yang mereka pilih dan yang akan dijadikan usaha guna mengembangkan kemampuan dan potensi yang mereka miliki. Dalam tahap ini perempuanperempuan diajarkan bagaimana mereka harus memiliki kemampuan dalam memanajemen usaha, mengelola keuangan, memimpin, memasarkan dan menginovasikan sehingga dapat diterima di tengahtengah masyarakat.

\section{Penerapan}

Dimana dalam tahap penerapan perempuan-perempuan tersebut diberi kesempatan dalam meningkatkan kapasitas mereka melalui usaha apa yang mereka akan lakukan serta melalui pilihan tersebut masyarakat akan mendapatkan pelatihan dalam menentukan jeenis usaha hendaknya memperhatika minat dan kemampuan yang dimiliki masing perempuan yang mengikuti kegiatan tersebut wajib menentukan jenis usaha berdasarkan potensi yang dimiliki desa dan tentunya mempertimbangkan kemampuan diri sendiri Para perempuan dibentuk dalam kelompok kecil untuk memudahkan masyarakat untuk saling bekerjasama, usaha yang diambil berdasarkan potensi yang dimilki. Perempuan memulai usaha bersama-sama dengan kelompok atau secara individu. disini semkain terlihat peran kearifan lokal Kuma dimanfaatkan dimana dalam mengembangkan usaha tersebut membutuhkan tenaga dalam mengerjakan usaha yang digeluti tentunya perempuan-perempuan yang menjalankan kegiatan Kuma mendapat kesempatan untuk belajar agar perempuan yang ada di dusun tersebut bisa mendapatkan sumber penghasilan lain melalui suatu usaha yang dimiliki masyarakat tersebut.

\section{Pelatihan Berkesinambungan}

Pelatihan berkesinambungan bertujuan memberikan kesempatan kepada para perempuan untuk memecahkan kesulitan dalam mengembangkan usaha tersebut tentunya pelatihan ini dilakukan berdasarkan kebutuhan merekaDalam memulai usaha pasti terdapat hal-hal yang terjadi dan semua berkaitan dengan masalah yang mereka hadapi tentunya dalam menghadapi masalah diperlukan solusi untuk dapat mendapatkan jalan keluarnya.
Kegiatan usaha yang dijalankan oleh perempuanperempuan disini harus mendapatkan pendampingan berupa pelatihan berkesinambungan yang tujuannya untuk memberikan pelatihan berkelanjutan sesuai dengan permasalahan yang mereka alami dilapangan, misalnya dalam menjalankan kegiatan usaha mereka ternyata masih lemah dalam cara pemasaran, maka yang dilakukan adalah pemberian pelatihan berupa cara bagaimana cara memasarkan produk agar mendapat tempat dimasyarakat, atau dalam menjalankan usaha tersebut masyarakat masih belum maksimal dalam mengelola keuangan diperlukan pelatihan serta pendampingan secara intensif sehingga perempuan-perempuan tersebut dapat mandiri, di bidang lainnya misalnya mereka dalam pengemasan produk belum dapat memberikan kemasan yang baik, maka diperlukan pelatihan khusus untuk dapat mendampingi para perempuan dalam memilih kemasan yang menarik dan serta mempunyai nilai ekonomis dihadapan konsumen. Kegiatan pelatihan tersebut tentunya haruslah sesuai dengan apa yang mereka butuhkan dan mendapat dukungan dari pemerintah desa agar .

Dari pemaparan diatas dapat disimpulkan konsep yang dilakukan untuk meningkatkan ekonomi perempua dayak Banyadu di dusun Simpang Tiga adalah: dalam tahap 1 dan 2 Menyadarkan masyarakat yang terdiri dari Koordinasi, analisis situasi dan menggali potensi diri dan potensi desa. Tahap 3 dan 4 peningkatan kemampuan masyarakat melalui persiapan pelatihan, pelatihan dasar. Tahap 5 dan 6 penerapan yang terdiri dari, menentukan jenis usaha berdasarkan potensi, memulai usaha serta tahap 7 mendapatkan pelatihan berkesinambungan yang tujuannya untuk memberikan pelatihan berkelanjutan sesuai dengan permasalahan yang mereka alami dilapangan adapun gambaran konsep peningkatan ekonomi perempuan dayak Banyadu adalah sebagai berikut melalui adalah:

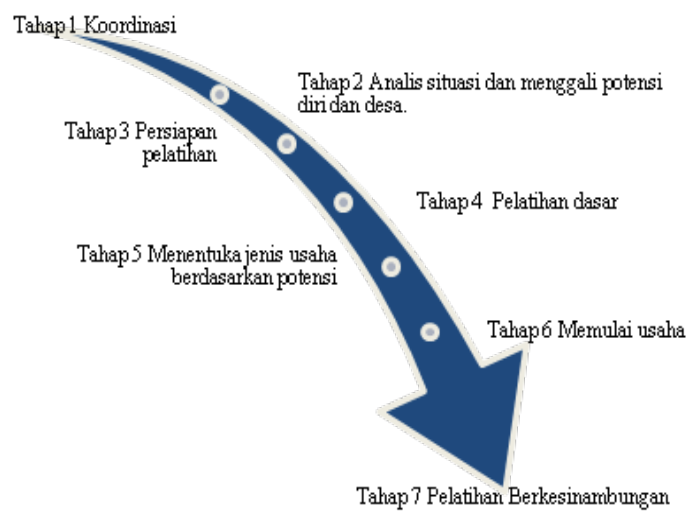

Gambar 3. Konsep peningkatan ekonomi perempuan dayak Banyadu melalui kearifan lokal Kuma. 


\section{SIMPULAN}

Kegiatan kearifan lokal Kuma di Dusun Simpang Tiga sangat bermanfaat bagi perempuan yanga da didusun tersebut,diperlukan dukungan bagi pemerintah desa untuk dapat mendukung kegiatan tersebut melalui pelatihan, pelatihan yang dilakukan dalam rangka meningkatkan peran serta kaum perempuan dalam meningkatkan kegiatan ekonomi di dalam Rumah tangga, dengan meningkatnya ekonomi rumah tangga maka tingkat kesejahteraan dapat terlihat dari segi pendidikan dan kesehatan rumah tangga tersebut.

Pelatihan tersebut juga hendakya sesuai dengan keadaan masyarakat setempat diantaranya melalui pelatihan berbasis pemberdayaan dimana kegiatan tersebut terdiri dari tahap 1 dan 2 Menyadarkan masyarakat yang terdiri dari Koordinasi, analisis situasi dan menggali potensi diri dan potensi desa. Tahap 3 dan 4 peningkatan kemampuan masyarakat melalui persiapan pelatihan, pelatihan dasar. Tahap 5 dan 6 penerapan yang terdiri dari, menentukan jenis usaha berdasarkan potensi, memulai usaha serta tahap 7 mendapatkan pelatihan berkesinambungan yang tujuannya untuk memberikan pelatihan berkelanjutan sesuai dengan permasalahan yang mereka alami dilapangan. Semua tahap yang dilakukan tentunya perlu mendapatkan evaluasi dari evaluasi tersebut akan muncul permasalahan sehingga diperlukan solusi.

Namun dalam melakukan kegiatan pelatihan tersebut diperlukan narasumber-narasumberr yang memiliki keahlian dibidangnya agar materi yang diberikan tepat sasaran dan bermanfaat bagi para perempuan di dusun Simpang Tiga. Narasumber yang memiliki keahlian dibidangnya misalnya untuk kegiatan pemasaran, semua berkaitan dengan brand, harga, kualitas produk, tempat, narasumber yang benar-benar pernah mengalami dan sudah mendapatkan tentunya sudah mempunyai pengalaman di bidang bisnis.

Selanjutnya adalah dukungan dari pemerintah terutama pemerintah desa dusun Simpang Tiga karena dalam menjalankan kegiatan tidak lepas dari kerjasama baik pemerintah kabupaten, pemerintah desa, warga masyarakat sendiri, semakin banyak yang ikut berpartisipasi tentunya berdampak pada pelaksanaan kegiatan sehingga kegiatan tersebut dapat terkoordinasi dengan baik dan dapat diterima oleh masyarakat yang membutuhkan.

\section{DAFTAR PUSTAKA}

Azizah, S.N. (2017). Pengembangan Ekonomi Kreatif Berbasis Kearifan Lokal Pandanus Handicraft dalam Menghadapi Pasar Modern Perspektif Ekonomi Syariah (Study Case di Pandanus Nusa Sambisari Yogyakarta ), 17, 63-78.
Bambang, S., Handoko, W. \& Sabiq, A. (2013). model community development sebagai strategi pemberdayaan berbasis kearifan lokal. Jurnal Review Politik, 03, (02), 298-312.

Diah, M.P. (2019). Peranan Kreativitas dan Inovasi dalam Peningkatan Produktivitas UMKM Pengolah Mangga Podang (Studi Pada Kelompok Tani Wanita "Budidaya" Desa Tiron Kecamatan Banyakan Kabupaten Kediri). Jurnal Ilmiah Administrasi Publik (JIAP), 5, (2), 152-156.

Elizabeth, R. (2008). Peran Ganda Wanita Tani dalam Mencapai Ketahanan Pangan Rumah Tangga di Pedesaan. Journal Iptek Tanaman Pangan, Kementerian Pertanian - Republik Indonesia, 3, (1), 59-68.

Frida, N.R.(2017).PeranPerempuanDalam Meningkatkan Perekonomian Keluarga Melalui Program P2wkss Di Sumber Gamol, Balecatur, Gamping, Sleman. Jurnal Social Studies Pendidikan IPS Universitas Negeri Yogyakarta, 6, (4), 406-418.

Kamonthip, K. (2007). Local Wisdom, Environmental Protection And Community Development: The Clam Farmers In Tambon Bangkhunsai, Phetchaburi Province, Thailand. MANUSYA: Journal of Humanities, 10, (1), 1-10.

Kantirina, R. (2019). Effectiveness of regional autonomy in building empowerment of human resources in rural communities. Sosiohumaniora, 21, (1), 17-21. http://doi.org/10.24198/sosiohumaniora. v21i1.11974

Khusnul, K. (2009). Diskriminasi Gender Terhadap Perempuan Dalam Sektor Pekerjaan. Yinyang: Jurnal Studi Islam, Gender and Anak,STAIN Purwokerto, 4, 1.

Neni, R.P.N. (2012). The Value of Education in Paddy Cultivation of Kanayatn Dayak in West. Balai Pelestarian Sejarah Dan Nilai Tradisional Pontianak, 15-25.

Pattinama, M. J. (2009). Pengentasan Kemiskinan Dengan Kearifan Lokal (Studi Kasus Di Pulau BuruMaluku Dan Surade-Jawa Barat). Makara, Sosial Humaniora, 13, (1), 1-12.

Boakye-Achampong, S., Mensah, J.O., Aidoo, R.K. O.-A. (2012). The Role of Rural Women in the Attainment of Household Food Security in Ghana: A Case Study of Women- Farmers in EjuraSekyeredumasi District. International Journal of Pure and Applied Sciences and Technology, 12, (1), 29-38. 
Silvi, \& Lumangkun, A.E.W. (2017). Kearifan Lokal Masyarakat Dalam Kegiatan Ladang Berpindah Di Dusun Laek Desa Bengkilu Kecamatan Tujuh Belas Kabupaten Bengkayang. Jurnal Hutan Lestari, 5, (4), 1027-1034.

Siti, K. \& Suyadnya, I.W. (2018) Metodologi penelitian kualitatif berbagi pengalaman dari lapangan, PT Raja Grafindo Persada, Depok

Sopa, M. (2018). Local Wisdom in the Cultural Symbol of Indonesian Traditional House, 524-531. http://doi. org/10.18502/kss.v3i4.1962
Suharto, T. (2016). Konsep dasar pendidikan berbasis masyarakat. ResearchGate, (December 2005), 3.

Sungkharat, U. (2010). Local Wisdom : The Development Of Community Culture And Production Processes In Thailand. International Business and Economics Research Journal, 9, (11), 115-120.

Utama, D.K.M.B. (2013). Kearifan Lokal dan Lingkungan. PT.Gading Inti Prima dan Pusat Penelitian dan Pengembangan Kebudayaan, Kementerian Pendidikan dan Kebudayaan RI. 